\title{
From mantle roots to surface eruptions: Cenozoic and Mesozoic continental basaltic magmatism
}

\author{
Horst Kämpf $^{1} \cdot$ Karoly Németh $^{2} \cdot$ Jacek Puziewicz $^{3} \cdot$ Jan Mrlina $^{4} \cdot$ \\ Wolfram H. Geissler ${ }^{5}$
}

Received: 21 September 2015 / Accepted: 21 September 2015 / Published online: 17 October 2015

(C) Springer-Verlag Berlin Heidelberg 2015

Basaltic volcanism is an important process in shaping large areas of the Earth's surface, not only in continental extensional environments and at the ocean floor.

This special issue contains a collection of fifteen papers that are dedicated to recent researches on various aspects of continental basaltic magmatism from its mantle roots via the ascent paths of the melt to the surface where different styles of volcanism take place erupting lavas or through explosive volcanism depositing various types of pyroclasts. Two of the fifteen were published earlier (Downes et al. 2015; Herrero-Hernandez et al. 2015). Continental basaltic volcanism also contributes to the total terrestrial sedimentary budget not only by its primary pyroclastic deposits but also their reworked varieties. Most of the papers result from presentations at the BASALT 2013 conference, which took place from April 18-24, 2013, in Görlitz, Germany (Büchner et al. 2013). The conference was organized by the Senckenberg Museum of Natural History Görlitz and co-organized by

Horst Kämpf

kaempf@gfz-potsdam.de

1 German Research Centre for Geosciences GFZ Potsdam, Telegrafenberg, 14473 Potsdam, Germany

2 Volcanic Risk Solutions, Institute of Agriculture and Environment, Massey University, Private Bag 11 222, Palmerston North, New Zealand

3 Institute of Geological Sciences, University of Wrocław, Pl. M. Borna 9, 50-204, Wrocław, Poland

4 Institute of Geophysics, Czech Academy of Sciences, Bocni II/1401, 14131 Prague, Czech Republic

5 Alfred-Wegener-Institut, Helmholtz-Zentrum für Polar- und Meeresforschung, Am Alten Hafen 26, 27568 Bremerhaven, Germany the International Association of Volcanology and Chemistry of the Earth's Interior (IAVCEI)-particularly its Commission on Monogenetic Volcanism-and the "Sächsische Landesstiftung Natur und Umwelt" LaNU Academy). Since the conference was held in the heart of Europe in Germany with accompanied field excursions to Poland and the Czech Republic, many contributions are related to the Cenozoic Central European Volcanic Province (Fig. 1). However, there was also a variety of contributions about Mesozoic and Cenozoic basaltic rocks worldwide. This variety is reflected in this issue.

The issue brings together studies on different aspects of basaltic magmatism. Thus, this volume contains petrological and geochemical studies spanning from studies of mantle peridotites to those on volcanic rocks as well as papers presenting geophysical data and interdisciplinary interpretation.

The issue starts with five papers discussing processes of basaltic melt generation in the upper mantle from asthenospheric or lithospheric source rocks. Puziewicz et al. show in their study that the subcontinental lithospheric mantle beneath Lower Silesia and Upper Lusatia (Poland) differs from the western to the southern region of the province. The Lower Silesia-Upper Lusatia domain records extensive depletion, which was followed by chromatographic-style metasomatism by mixed carbonatite-silicate melts. In contrast to other areas further west- and southwestwards, the spinel-facies xenolith suites mostly consist of clinopyroxene-free harzburgite (olivine Fo 90.5-92.0 mol \%; group "A"). This harzburgitic Al-depleted lithospheric mantle is related to the Variscan paleotectonic setting. The occurrences of " $\mathrm{B}$ " harzburgites containing less magnesian olivine (Fo 84.0-90.0 mol \%) reflect supposedly Cenozoic "Fe-metasomatism" by silicate melts. Medaris et al. studied a layered lithospheric mantle on a suite of spinel peridotite 


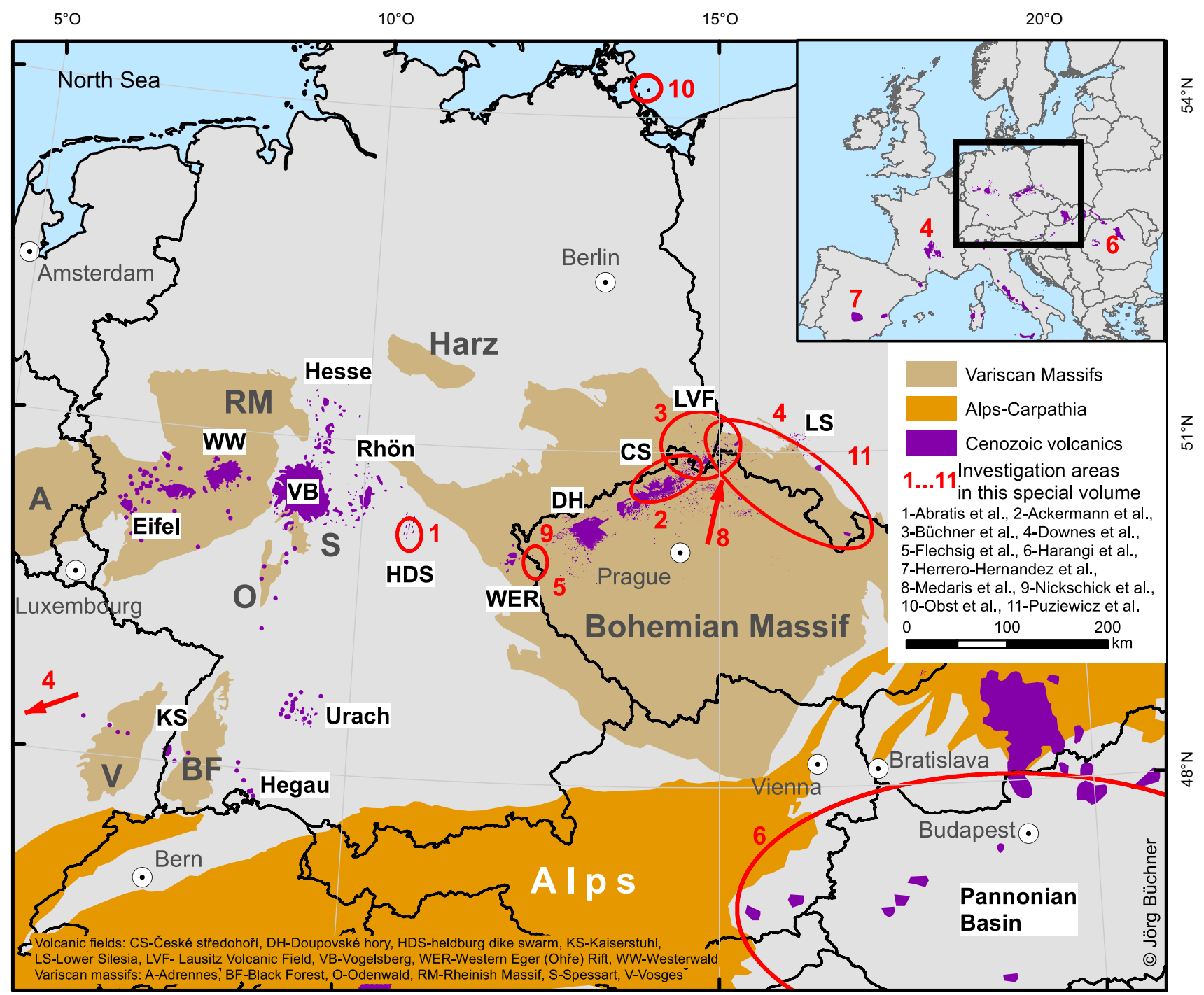

Fig. 1 Location of research areas in the Central European volcanic province (completed according to Büchner et al. this volume)

xenoliths from the Kozákov volcano in the Elbe/Labe Zone (Czech Republic). Since 1999 four papers have been published over the same topic, reflecting the general interest to understand this region. Authors present first $\mathrm{Li}$ isotopic data on the Kozákov site (12 samples) and completed the upper part of the "sub-Kozakov lithospheric mantle profile", adding new data. They discuss a depth profile through the mantle lithosphere varying in equilibration temperature from 675 to $1135{ }^{\circ} \mathrm{C}$ and providing continuous sampling from the Moho to a depth of ca. $82 \mathrm{~km}$. Li isotope compositions varying from -0.8 to $-5.4 \%$ reflect the effect of pervasive metasomatic events. The study of Ackerman et al. brings new data on petrology of subcontinental lithospheric mantle beneath the Northern Bohemia (Česke Středohoři Volcanic complex/CSVC and Upper Lusatia). The xenoliths from CSVC are mostly harzburgites (olivine Fo 90.0-91.6 mol \%) and show high degrees of partial melting (ca. 17-21\%). CSVC xenoliths were metasomatized by silicate melt at high melt/rock ratios, while those from Northern Upper Lusatia were metasomatized by alkaline and $\mathrm{CO}_{2}$-bearing melts at low melt/rock ratios. Comparable to the results of Puziewicz et al. the subcontinental lithospheric mantle of the Česke Středohoři Volcanic complex and Upper Lusatia demonstrate compositional heterogeneity and imply similar open questions as raised by Puziewicz et al. Downes et al. (2015) studied Hf-Zr anomalies in clinopyroxenes of mantle xenoliths from France and Poland and discuss the potential of applying the $\mathrm{Lu}-$ Hf system of dating to garnet-free mantle rocks. Whereas the afore four papers discussed processes in the lithospheric root zone of basaltic magmas using small pieces of rocks from the upper mantle (xenoliths), Estrada use petrographic, element geochemic, $\mathrm{Sr}-\mathrm{Nd}$ isotope data and $\mathrm{Ar}-\mathrm{Ar}$ whole rock age determinations within an Early- to 
mid-Cretaceous continental flood basalt suite in the Canadian High Arctic (Strand Fjord and Hassel basalts, Isachsen basalts) to get hands on the mantle sources and magmatic evolution of these rocks.

The second part of this special issue consists of five papers focus on the origin, ascent, emplacement and composition of basaltic magmas and mantle-derived gases. Harangi et al. provide a cutting edge review based on over two decades of research on the origin and geodynamic relationships of the Late Miocene to Quaternary alkaline basalt volcanism within the Pannonian Basin in eastern-central Europe by looking at petrological and geochemical characteristics as well as their temporal evolution. Assuming the basalts represent primitive melts, the authors constrain conditions of magma generation. Harangi et al. discuss why they think that regional alkaline basaltic volcanism is controlled by plate tectonics and asthenospheric flow influenced by strong topography at the lithosphere-asthenosphere boundary instead of a mantle plume or finger. Abratis et al. follow the question how spinel lherzolite xenoliths from the upper mantle make its way into a phonolite of the Heldburg dike swarm (Germany), commonly accepted to be differentiated at crustal depths. The authors provide evidence from petrographical, mineral chemical investigations and $\mathrm{Ar}-\mathrm{Ar}$ age determinations for extensive mixing and mingling of two coeval melts with different compositions before $15 \mathrm{Ma}$. This implies the intrusion of a primitive mafic magma into an existing magma chamber with an already evolved magma. Büchner et al. (a, b) give a comprehensive insight into the Lausitz (Lusatia) Volcanic Field (Germany), which they define as a temporally and spatially bounded part of the Central European Volcanic Province. Their study includes various aspects on volcanic textures indicative for various eruption styles, geochemistry and age determinations of more than 300 rocks from 123 localities providing a tremendous new set of original data from a less known volcanic region. The cover-figure of the special issue originates from this contribution (Figure 4) and shows Landeskrone volcano, located ca. $5 \mathrm{~km} \mathrm{SW}$ of Görlitz (ArAr age: $31.8 \mathrm{Ma}$ ).

One of the two geophysical papers provides a comprehensive view on the inner and outer structure of a maar-diatreme volcano. Flechsig et al. investigated in an integrated way the Mýtina maar, the first known Quaternary maar in the Bohemian Massif (Mrlina et al. 2009). They applied various geophysical and geological/petrochemical methods and found evidence for circular fracture zones outside the maar, the distribution of eruption-related deposits as well as indications for paleotopography of the landscape before the eruption took place. Nickschick et al. deal with the most important known magmatic activity within the Central European Volcanic Province. They map diffuse mantlederived carbon dioxide emissions in the Hartoušov moffete field in the western Eger Rift and discuss the problems in quantifying time-variant and diffuse gas fluxes by the application of geostatistic tools. Nickschick et al. employ gas flux, soil gas with gravity and geoelectric measurements to generally understand near-surface conditions and processes of $\mathrm{CO}_{2}$ degassing in wet and dry mofette fields, its potential control by an existing tectonic framework, and properties of the underlying rock and sediments.

The third part of the special issue deals with the surface expression of basaltic volcanism, volcanologic and sedimentologic research and volcanism-sedimentation interaction processes in five papers. Németh and Kereszturi provide in their review article some personal view on what they understand under the terminus "monogenetic volcanism". The authors evaluate the history and existing ideas on this widely and often used conceptional terminus. Constructing theoretical cross sections and providing field evidence mostly from New Zealand and Saudi Arabia, the authors propose a new definition of monogenetic volcanism that could much better explain the existing chemical and volcanic architecture diversity. Sheth and Canón-Tapia continue and discuss the fundamental conceptual question if flood basalt eruptions are monogenetic or polygenetic. As base of their study they use new field evidence from the Deccan Traps volcanic province in western India. Further field data from Hawaii and Iceland is included into the discussion. Finally, Sheth and Canon-Tapia ask to use a clear terminology in describing different types of volcanic edifices. Herrero-Hernandez et al. (2015) give insights into interaction between volcanism and fluvio-lacustrine sedimentation by studying the Campo de Calatrava Volcanic Field (Spain) using magnetostratigraphy and geochronology techniques. They describe and interpret volcaniclastic deposits and develop a sedimentologic conceptual model of the study area, which takes into consideration the various detected types of volcaniclastic deposits. They are interpreted by Herrero-Hernandez et al. to originate from monogenetic volcanoes, as there are scoria cones, tuff rings and maars. Rani et al. report on a highly applied study of the basaltic glass from the Deccan Traps volcanic field (Osham Hill; age: $\sim 66 \mathrm{Ma})$. They investigated its suitability as a radioactive waste containment matrix with respect to the alteration behavior. Rani et al. describe alteration processes and compare glass sample after alteration experiments with naturally altered glass. Finally, Obst et al. provide an extensive description on the early Eocene volcanic ashes occurring as ash-bearing carbonate concretion (cementstones) on the Greifswalder Oie, NE Germany, that belong to pyroclastic deposits within the large North Atlantic Igneous Province (NAIP). They differentiate two types based on mineralogical composition, sedimentary features and fossil content. Furthermore, Obst et al. discuss the origin of the volcanic ashes by comparing them with coeval ash-bearing 
deposits in Northern Germany and Denmark, as well as alteration of these ashes during sedimentation and reworking in a shallow marine environment. The contribution bridged a gap in the modern research literature because the knowledge of the ash layers in the German deposits is only known from older publications.

Acknowledgments We are grateful to the organizing committee of the BASALT 2013 conference, Jörg Büchner, Olaf Tietz and Helga Zumkowski-Xylander, Senckenberg Museum of Natural History Görlitz and Vladislav Rapprich, Czech Geological Survey, Prague. Special thanks to the Editor-in-Chief of the International Journal of Earth Sciences, Wolf-Christian Dullo, who supported the idea of this special issue and Monika Dullo for kind help. Thanks also to Marion Tichomirowa for editorial handling of one of the manuscripts. We gratefully acknowledge all the reviewers, for their critical and constructive evaluation of the contributions. Funding of the BASALT 2013 conference by the German Research Foundation is gratefully acknowledged. Cover figure and Figure 1 by Jörg Büchner.

\section{References}

Büchner J, Rapprich V, Tietz O (eds) (2013) Abstracts and excursion guides to the scientific conference "Basalt 2013-Cenozoic Magmatism in Central Europe”, Görlitz, 24.-28.04.2013, p 309, Prague (Czech Geol. Surv.), ISBN 978-80-7075-806-9

Downes H, de Vries C, Wittig N (2015) Hf-Zr anomalies in clinopyroxene from mantle xenoliths from France and Poland: implications for Lu-Hf dating of spinel peridotite lithospheric mantle. Int. J. Earth Sci 104(1):89-102. doi:10.1007/s00531-014-1074-x

Herrero-Hernandez A, Lopez-Moro FJ, Gallardo-Millan JL, MartinSerrano A, Gomez-Fernandez F (2015) Volcanism-sedimentation interaction in the Campo de Calatrava Volcanic Field (Spain): a magnetostratigraphic and geochronological study. Int J Earth Sci 104(1):103-122. doi:10.1007/s00531-014-1053-2

Mrlina J, Kämpf H, Kroner C, Mingram J, Stebich M, Brauer A, Geissler WH, Kallmeyer J, Matthes H, Seidl M (2009) Discovery of the first quaternary maar in the Bohemian Massif, Central Europe, based on combined geophysical and geological surveys. J Volcanol Geother Res 182:97-112. doi:10.1016/j.jvolgeores.2009.01.027 